\title{
Genetic parameters of subclinical macromineral disorders and major clinical diseases in postparturient Holstein cows
}

\author{
V. Tsiamadis, ${ }^{*}$ G. Banos, ${ }^{\dagger} \dagger$ N. Panousis, $¥$ M. Kritsepi-Konstantinou, $\S$ G. Arsenos, ${ }^{*}$ and G. E. Valergakis ${ }^{* 1}$ \\ *Department of Animal Production, Faculty of Veterinary Medicine, Box 393, Aristotle University of Thessaloniki, GR-54124 Thessaloniki, Greece \\ †Roslin Institute, Scotland's Rural College, Edinburgh, Scotland, UK EH25 9RG \\ $\ddagger$ Clinic of Farm Animals, and \\ §Diagnostic Laboratory, Department of Clinics, Faculty of Veterinary Medicine, Aristotle University of Thessaloniki, GR-54124 Thessaloniki, \\ Greece
}

\section{ABSTRACT}

The main objective of this study was to assess the genetic parameters of subclinical disorders associated with subclinical hypocalcemia, hypophosphatemia, subclinical hypomagnesemia, hypokalemia, and hyperphosphatemia, as well as major clinical diseases after calving in Holstein cows. The secondary objective was to estimate the associated genetic and phenotypic correlations among these subclinical and clinical conditions after calving in Holstein cows. The study was conducted in 9 dairy herds located in Northern Greece. None of the herds used any kind of preventive measures for milk fever (MF). A total of 1,021 Holstein cows with pedigree information were examined from November 2010 until November 2012. The distribution across parities was 466 (parity 1), 242 (parity 2), 165 (parity 3), and 148 (parity 4 and above) cows. All cows were subjected to a detailed clinical examination and blood was sampled on d 1, 2, 4, and 8 after calving. Serum concentrations of $\mathrm{Ca}, \mathrm{P}, \mathrm{Mg}$, and $\mathrm{K}$ were measured in all samples, whereas $\beta$-hydroxybutyrate (BHB) was measured only for $\mathrm{d} 8$. The final data set included 4,064 clinical and 16,848 biochemical records (4,020 Ca, 4,019 P, 4,020 Mg, 3,792 K, and $997 \mathrm{BHB}$ ). Data of 1,988 observations of body condition score at d 1 and 8 were also available. All health traits were analyzed with a univariate random regression model. The genetic analysis for macromineral-related disorders included 986 cows with no obvious signs of MF (35 cows with MF were excluded). Analysis for other health traits included all 1,021 cows. A similar single record model was used for the analysis of BHB. Genetic correlations among traits were estimated with a series of

Received December 21, 2015.

Accepted July 18, 2016.

${ }^{1}$ Corresponding author: geval@vet.auth.gr bivariate analyses. Statistically significant daily heritabilities of subclinical hypocalcemia (0.13-0.25), hypophosphatemia (0.18-0.33), subclinical hypomagnesemia (0.11-0.38), and hyperphosphatemia $(0.14-0.22)$ were low to moderate, whereas that of hypokalemia was low (0.08-0.10). The heritability of body condition score was $0.20 \pm 0.10$. Statistically significant daily heritabilities of clinical diseases were those of MF (0.07-0.11), left displaced abomasum (0.19-0.31), and mastitis (0.15-0.41). Results suggest that these health disorders are heritable traits and could be minimized with proper genetic selection. Statistically significant phenotypic correlations were estimated for the first time between macromineral concentrations and almost all transition cow metabolic and infectious health disorders.

Key words: subclinical macromineral disorders, postpartum diseases, genetic parameters

\section{INTRODUCTION}

During the transition period ( $3 \mathrm{wk}$ before to $3-4 \mathrm{wk}$ after calving), the modern high-producing dairy cow is at increased risk of encountering a multitude of interrelated health disorders (Larsen et al., 2001; Lean et al., 2013). In a study that included 151,000 records, Ingvartsen et al. (2003) clearly demonstrated that disease incidence is highest during the first $10 \mathrm{~d}$ after calving. Negative energy balance, macromineral-related disorders, and reduced immunity are the 3 major causes of transition period diseases (Goff, 2006a). Prevention of health disorders around calving is based on the implementation of various managerial and nutritional strategies; for example, $\mathrm{BCS}$ evaluation and postcalving $\mathrm{BHB}$ serum concentration are proposed to be routinely used as energy balance indicators (Oikonomou et al., 2008a; LeBlanc, 2010).

Macromineral serum concentration changes are mainly caused by increased cow requirements at the onset of lactation combined with reduced feed intake and possibly delayed homeostatic mechanisms (Goff, 
2006a). Macromineral-related disorders, relating to Ca, $\mathrm{P}, \mathrm{Mg}$, and $\mathrm{K}$ concentrations, are at the center of the disease cascade that dairy cows experience during the transition period (Goff, 2004), in either clinical or subclinical form (Goff, 2006b).

Subclinical hypocalcemia (SCHCa, serum Ca concentration $<8.3 \mathrm{mg} / \mathrm{dL}$ ) is by far the most common macromineral-related health disorder associated with calving (Horst and Goff, 2003; Goff, 2008; Peek and Divers, 2008). Clinical hypocalcemia (parturient paresis: milk fever, MF) has a detrimental role in major postcalving clinical disease incidence, since it is associated with: retained fetal membranes (RFM), metritis (MET), mastitis (MAST), displaced abomasum (left or right, LDA and RDA, respectively), ketosis (KET), and uterine prolapse (UP; Correa et al., 1990; Gröhn and Bruss, 1990; DeGaris and Lean, 2008). Subclinical hypocalcemia is assumed to have the same negative effects but relevant literature is lacking.

Lower than normal $\mathrm{P}$ concentrations (HypoP, P $<4.2 \mathrm{mg} / \mathrm{dL}$ ) are common at the onset of lactation; recumbent MF dairy cows often have very low $\mathrm{P}$ concentration $(\mathrm{P}<2.0 \mathrm{mg} / \mathrm{dL}$; Goff, 2004). Elevated $\mathrm{P}$ concentrations (HyperP, P $>7.80 \mathrm{mg} / \mathrm{dL}$ ) increase the risk of MF (Lean et al., 2013; Grünberg, 2014). While clinical hypomagnesemia ("grass tetany," serum $\mathrm{Mg}<1.0 \mathrm{mg} / \mathrm{dL}$ ) may still appear in grazing herds, it is not at all common in confined and TMR-fed cows (Peek and Divers, 2008). On the other hand, subclinical hypomagnesemia (SCHMg, serum $\mathrm{Mg}<1.8 \mathrm{mg} / \mathrm{dL}$ ) is involved in the etiology of SCHCa and MF (Littledike et al., 1983; Rude, 1998; Schonewille et al., 2008). Mild hypokalemia (serum K between 2.6 and $3.8 \mathrm{mmol} / \mathrm{L}$ ) is common in early lactation (Sattler and Fecteau, 2014), while severe hypokalemia (serum $\mathrm{K}<2.5 \mathrm{mmol} / \mathrm{L}$ ) is very rare in dairy cattle, mostly associated with concurrent infectious disease (Sattler et al. 1998).

Macromineral-related disorders usually resolve by the end of the first week postcalving but their effects are long-lasting, impairing milk production and reproductive efficiency of dairy cows (Goff, 2006b). Despite the extensive knowledge regarding the pathophysiology of macromineral-related disorders and the various management practices that may alleviate them (ThilsingHansen et al., 2002; Goff, 2004; Mulligan et al., 2006), problems are still common. Disease incidence rates, even in many well-managed herds, still remain unacceptably high (Mulligan and Doherty, 2008). During the last decades, genetic selection for disease resistance enjoys increased popularity because genetic progress, no matter how small, is permanent and cumulative (Eggen, 2012). Genetic parameters for various clinical diseases around calving have been estimated in several large-scale studies (Lin et al., 1989; Lyons et al., 1991; Heringstad et al., 2005). Heritabilities of Ca, P, Mg, and $\mathrm{K}$ serum concentrations have only recently been reported (Tsiamadis et al., 2016); however, information concerning subclinical macromineral-related disorders is lacking.

The objectives of this study were to estimate: (1) the heritability of SCHCa, HypoP, HyperP, SCHMg, hypokalemia (HypoK), BHB, and BCS; (2) the heritability of major clinical health disorders (MF, RFM, MET, MAST, LDA, RDA, KET, and UP); and (3) relevant genetic and phenotypic correlations, during the first 8 d after calving.

\section{MATERIALS AND METHODS}

The research was conducted in compliance with institutional guidelines and approved by the Research Committee of the Aristotle University of Thessaloniki, Thessaloniki, Greece. All farmers gave informed consent for the cows to be included in the study and to undergo the testing procedures.

\section{Animals and Management}

A total of 1,021 Holstein cows from 9 commercial freestall dairy herds in northern Greece were included in the study. The distribution across parities was 466 , 242, 165, and 148 cows for parities 1, 2, 3, and 4 and above, respectively. Farms were visited regularly between November 2010 and November 2012 for data collection. No herd used any kind of preventive measures for hypocalcemia. Total mixed rations were formulated to meet or exceed net energy and MP requirements according to NRC (2001) recommendations.

\section{Clinical Examination, Blood Sampling, and Analyses}

All animals were clinically examined and blood sampled by the first author on d 1, 2, 4, and 8 after calving. Body condition score was recorded on d 1 and 8 after calving using the 1- to 5-point scale of Ferguson et al. (1994), in increments of 0.25 . At this scale, $1=$ emaciated and $5=$ obese animals.

Blood sampling was performed by coccygeal venipuncture into 10-ml vacuum glass tubes without anticoagulant (BD Vacutainer, Plymouth, United Kingdom) for serum macromineral measurements. Samples were placed in a cooler, transported to the Diagnostic Laboratory of the Faculty of Veterinary Medicine, and centrifuged immediately upon arrival $(3,000 \times g$ for $15 \mathrm{~min}$, room temperature: $21^{\circ} \mathrm{C}$ ). Serum was transferred into polyethylene tubes and stored at $-80^{\circ} \mathrm{C}$ until assay. All 
sera were analyzed for total $\mathrm{Ca}$ and $\mathrm{Mg}$ concentrations using flame atomic absorption spectrophotometry (Perkin Elmer AAnalyst 100, Perkin Elmer Co, Norwalk, $\mathrm{CT}$ ), according to the manufacturer's instructions. Serum inorganic phosphorus concentrations were determined photometrically using a Flexor E autoanalyzer (Vital Scientific, Spankeren, the Netherlands), according to the procedure described by Daly and Ertingshausen (1972), with the use of standard commercial reagents (Thermo Fisher Scientific Inc., Waltham, MA). Potassium serum concentrations were measured using an ion-selective electrode according to the manufacturer's instructions (Electrolyte Analyzer 9180, Roche, Basel, Switzerland). The intra- and inter-assay coefficients of variation for all the above analyses were less than $3 \%$. Beta-hydroxybutyric acid was measured only on $\mathrm{d} 8$ after calving by a spectrophotometric kinetic method (Bruss, 2008). The intra-assay coefficient was 2 to $4 \%$, whereas the inter-assay coefficient was 4 to $8 \%$, both of which are within the desirable range.

\section{Disease Definitions and Cut-Offs}

In our study, SCHCa, HypoP, HyperP, SCHMg, and HypoK were defined based on threshold values provided in relevant literature and were expressed as presence or absence of the condition (binary traits). Animals with serum concentrations below or equal to $8.3 \mathrm{mg} /$ $\mathrm{dL}$ for $\mathrm{Ca}, 4.2 \mathrm{mg} / \mathrm{dL}$ for $\mathrm{P}, 1.8 \mathrm{mg} / \mathrm{dL}$ for $\mathrm{Mg}$, and $3.9 \mathrm{mmol} / \mathrm{L}$ for $\mathrm{K}$ were considered as cases of SCHCa, HypoP, SCHMg, and HypoK, respectively (Horst and Goff, 2003; Goff, 2008; Divers and Peek, 2008). Moreover, animals with inorganic serum $\mathrm{P}$ concentration $\geq 7.80 \mathrm{mg} / \mathrm{dL}$ were considered HyperP cases, whereas cows with serum $\mathrm{BHB} \geq 1,200 \mu \mathrm{mol} / \mathrm{L}$ were considered subclinically ketotic (Divers and Peek, 2008).

Clinical diseases were defined as follows: (a) MF, standing (showing mild ataxia, excitability, muscle tremors, and reduced ruminal motility) or recumbent cow (Kelton et al., 1998; Oetzel, 2011); (b) RFM, fetal membranes were visible at the vulva or were identified in the uterus by vaginal examination more than $12 \mathrm{~h}$ after calving (Melendez et al., 2003); (c) MET, fetid uterine discharge, with or without fever (Sheldon et al., 2006); (d) MAST, milk clots or abnormal mammary discharge from one or more quarters (Kelton et al., 1998); (e) KET, decreased appetite together with elevated blood BHB $(>2,000 \mu \mathrm{mol} / \mathrm{L})$, in the absence of obvious concurrent disease (Kelton et al., 1998; Duffield et al., 2009); (f) LDA/RDA, decreased appetite accompanied by a clearly audible "ping" sound, produced by percussion of the left/right abdominal wall (between the 9th and 12th ribs), respectively (Kelton et al., 1998).

\section{Data Set}

Pedigree information was available for all 1,021 cows (332 common sires and 786 common dams). The total population in the study increased to 4,262 animals, when all available pedigree information included, spanning the last 5 (overlapping) generations. Calving date, parity number, calving ease, and twinning were recorded. From the 1,021 cows, 35 were diagnosed with MF during the first $4 \mathrm{~d}$ after calving, treated appropriately with intravenous $\mathrm{Ca}$, and excluded from the genetic analysis of macromineral-related health traits. Therefore, 986 cows were included in the genetic analysis for SCHCa, HypoP, HyperP, SCHMg, and HypoK. However, genetic analysis for the other recorded clinical health traits (MF, RFM, MET, MAST, LDA, RDA, KET, and UP) included all 1,021 cows.

The final data set included 4,064 clinical observations for MF, RFM, MET, MAST, LDA, RDA, KET, and UP. Moreover, observations for death (DE) and involuntary culling (INVCULL) during the same time-period were also included in the data set, as well as 1,988 BCS records. In total, 16,848 biochemical records were available, consisting of 4,020 $\mathrm{Ca}$, 4,019 $\mathrm{P}, 4,020 \mathrm{Mg}, 3,792 \mathrm{~K}$ (d 1, 2, 4, and 8 after calving), and 997 BHB (only on d 8) measurements. Changes of the macrominerals concentrations between $\mathrm{d} 1$ and 4 , as well as between $\mathrm{d} 1$ and 8 , were calculated as the regression slope of macromineral concentrations on time. Thus, these measurements reflected the average daily change in said concentrations and were treated as different traits.

\section{Statistical Analysis}

Macromineral-related and disease-related health traits measured on d 1 through 8 were analyzed with a random regression model, which accounted for the covariance between successive records of the same animal; each trait was analyzed separately:

$$
\begin{aligned}
& Y_{i j k m n}=H Y S_{i}+L_{j}+\mathrm{M}_{k}+a_{1} \cdot a g e \\
& +\sum_{m=0}^{2} b_{m} P_{m} D+\sum_{m=0}^{2} A_{n m} P_{m} D+e_{i j k m n},
\end{aligned}
$$

where $Y_{i j k m n}$ is the health trait record of cow $n$; $H Y S_{i}$ is the fixed effect of herd-year-season of calving $i$ (72 levels); $L_{j}$ is the fixed effect of number of lactation $j$ (4 levels); $M_{k}$ is the fixed effect of calendar month $k$ (12 levels); $a_{1}$ is the linear regression coefficient on age at calving (age); $P_{m}$ is the orthogonal polynomial of order $\mathrm{m} ; b_{m}$ is the fixed regression coefficient on days from calving $(D) ; A_{n m}$ is the random regression coefficient on 
days from calving associated with the additive genetic effect of cow $n$ including all pedigree data (4,262 animals spanning 5 generations); and $e_{i j k m n}$ is the random residual term.

The fixed effects in the model including the polynomial order in the fixed regression were fitted after preliminary analyses had confirmed their statistically significant effect $(P<0.05)$ on the traits based on the $F$-test. Further increasing the order of the polynomial did not have a significant effect $(P>0.05)$. Similarly, the final order of the random polynomial (third for either trait) was determined with the use of the loglikelihood ratio test in sequential analyses of gradually increasing orders. The final order choice was also confirmed with the Akaike information criterion test. Four measurement error classes were defined for each the day from calving (d 1, 2, 4, and 8). The definition of these classes, even at this small time span, aimed to capture the day-to-day differences in health events at the beginning of lactation. Covariances between the error classes were assumed to be zero.

A random permanent environment effect was also fitted to model [1] resulting in a practically zero corresponding variance component estimate, possibly due to the short period our data spanned $(8 \mathrm{~d})$. The loglikelihood ratio tests between the models including and excluding permanent environment were not significant $(P>0.05)$ in all analyses.

There was also an effort to fit a Logit function in model [1] to account for the binary nature of the disease traits. However, this was proved unfeasible within the context of a random regression model.

Serum BHB concentration for $\mathrm{d} 8$ from calving and average estimates for BCS on d 1 and 8 and serum concentration changes between $\mathrm{d} 1$ and 4 (d 1-4), as well as d 1 and 8 (d 1-8) after calving were analyzed using the following model:

$$
Y_{i j k m}=H Y S_{i}+L_{j}+a_{1} \cdot a g e+A_{k}+e_{i j k m},
$$

where $Y_{i j k m}$ is the log-transformed value for serum BHB concentration or BCS or macromineral concentration change of cow $k, A_{k}$ is the additive genetic effect of cow $k$, and all effects are as in model 1 .

Estimates of variance components from each model were used to calculate heritabilities for each trait, with the following equation:

$$
\mathrm{h}^{2}=\frac{\sigma_{\alpha}^{2}}{\sigma_{p}^{2}},
$$

where $\mathrm{h}^{2}=$ the heritability estimate, $\sigma_{\alpha}^{2}=$ the additive genetic variance, and $\sigma_{p}^{2}=$ the phenotypic variance.

Genetic $\left(r_{\alpha}\right)$ and phenotypic $\left(r_{p}\right)$ correlations among all traits analyzed with the above models were estimated based on co-variance components derived with a series of bivariate analyses based on the same model described for each trait, with the following equation:

$$
r_{(\alpha, p)}=\frac{\operatorname{Cov}_{(\alpha, p)}(\mathrm{X}, \mathrm{Y})}{\sqrt{\sigma_{(\alpha, p) \mathrm{X}}^{2} \times \sigma_{(\alpha, p) \mathrm{Y}}^{2}}},
$$

where $\operatorname{Cov}_{(\alpha, p)}(\mathrm{X}, \mathrm{Y})=$ the additive genetic $\left(\operatorname{Cov}_{\alpha}\right)$ or phenotypic $\left(\operatorname{Cov}_{p}\right)$ co-variance of traits $\mathrm{X}$ and $\mathrm{Y}$ and $\sigma_{(\alpha, p) \mathrm{X}}^{2}$ and $\sigma_{(\alpha, p) \mathrm{Y}}^{2}$ are the genetic $\left(\sigma_{\alpha}^{2}\right)$ or phenotypic $\left(\sigma_{p}^{2}\right)$ variances of relevant traits.

All analyses were conducted using the statistical software package ASREML (Gilmour et al., 2006). In all cases, statistical significance was set at $P<0.05$.

\section{RESULTS}

Descriptive statistics for $\mathrm{Ca}, \mathrm{P}, \mathrm{Mg}, \mathrm{K}$, and $\mathrm{BHB}$ serum concentrations and BCS are presented in Table 1. Average incidence of health disorders during the same time period after calving is presented in Table 2 .

Random regression model was used for the generation of prevalence curves across all lactations for all health disorders during the first $8 \mathrm{~d}$ after calving. However, this was possible only for SCHCa, HypoP, SCHMg, HypoK, and HyperP (Figure 1), and also

Table 1. Descriptive statistics of serum $\mathrm{Ca}, \mathrm{P}, \mathrm{Mg}, \mathrm{K}$, and $\mathrm{BHB}$ concentrations, and BCS during the first 8 d after calving

\begin{tabular}{lrcccc}
\hline Trait & Mean & SD & Minimum & Maximum & No. of cows \\
\hline Ca $(\mathrm{mg} / \mathrm{dL})$ & 8.92 & 0.77 & 3.9 & 13.9 & 1,021 \\
$\mathrm{P}(\mathrm{mg} / \mathrm{dL})$ & 5.21 & 0.89 & 1.1 & 10.5 & 1,021 \\
$\mathrm{Mg}(\mathrm{mg} / \mathrm{dL})$ & 2.24 & 0.26 & 0.36 & 7.2 & 1,021 \\
$\mathrm{~K}(\mathrm{mmol} / \mathrm{L})$ & 4.59 & 0.39 & 2.4 & 6.3 & 1,018 \\
$\mathrm{BHB}(\mu \mathrm{mol} / \mathrm{L})$ & 829.03 & 602.29 & 160 & 4,870 & 997 \\
BCS $(1-5 \mathrm{scale})$ & 3.12 & 0.41 & 1.75 & 4.75 & 977 \\
\hline
\end{tabular}


Table 2. Average incidence of health disorders during the first $8 \mathrm{~d}$ after calving (1,021 cows; all traits are expressed as binary traits) ${ }^{1}$

\begin{tabular}{lcc}
\hline Trait & Average & SD \\
\hline SCHCa & 0.634 & 0.482 \\
HypoP & 0.498 & 0.500 \\
SCHMg & 0.323 & 0.468 \\
HypoK & 0.229 & 0.421 \\
HyperP & 0.090 & 0.286 \\
MF & 0.080 & 0.272 \\
RFM & 0.176 & 0.381 \\
MET & 0.337 & 0.473 \\
MAST & 0.099 & 0.299 \\
LDA & 0.035 & 0.185 \\
RDA & 0.001 & 0.031 \\
KET & 0.029 & 0.169 \\
UP & 0.003 & 0.054 \\
INVCULL & 0.005 & 0.070 \\
DE & 0.008 & 0.088 \\
\hline
\end{tabular}

${ }^{1} \mathrm{SCHCa}=$ subclinical hypocalcemia, HypoP $=$ hypophosphatemia, SCHMg $=$ subclinical hypomagnesemia, HypoK = hypokalemia, HyperP $=$ hyperphosphatemia, $\mathrm{MF}=$ milk fever, $\mathrm{RFM}=$ retained fetal membranes, MET $=$ metritis, $\mathrm{MAST}=$ mastitis, $\mathrm{LDA}=$ left displacement of abomasum, RDA = right displacement of abomasum, $\mathrm{KET}=$ clinical ketosis, UP $=$ uterine prolapse, INVCULL $=$ involuntary culling, $\mathrm{DE}=$ death.

for MF, LDA, and MAST (Figure 2). The remaining health disorders had either low incidence (RDA, UP, INVCULL, DE), or were not present throughout the entire 8-d period (RFM: present only d 1; MET, KET: present mainly after d 4), thus rendering it impossible to generate curves.

Day-to-day variances (phenotypic, genetic, and residual) and heritabilities for SCHCa, HypoP, SCHMg, HypoK, and HyperP are shown in Table 3 and for MF, LDA, and MAST in Table 4. All estimates presented were statistically greater than zero $(P<0.05)$. Dayto-day heritability estimates were low to moderate for SCHCa $\left(\mathrm{h}^{2}=0.13-0.25\right)$, HypoP $\left(\mathrm{h}^{2}=0.18-0.33\right)$, HyperP $\left(\mathrm{h}^{2}=0.14-0.22\right), \operatorname{SCHMg}\left(\mathrm{h}^{2}=0.11-0.38\right)$, and LDA $\left(\mathrm{h}^{2}=0.19-0.31\right)$; low for HypoK and MF $\left(\mathrm{h}^{2}=0.07-0.11\right)$; and moderate to high for MAST $\left(\mathrm{h}^{2}\right.$ $=0.15-0.41)$. Regarding serum BHB, the heritability estimate was not statistically significant $\left(\mathrm{h}^{2}=0.073\right.$ $\pm 0.077, P=0.12)$, but was statistically significant for BCS $\left(\mathrm{h}^{2}=0.20 \pm 0.10, P<0.05\right)$.

Significant genetic correlations: (a) between serum $\mathrm{Ca}, \mathrm{P}, \mathrm{Mg}$, and $\mathrm{K}$ concentrations and health disorders; (b) of macromineral concentration changes in d 1 to 4 and $\mathrm{d} 1$ to 8 after calving with health disorders; and (c) among health disorders were not detected in the present study.

Statistically significant phenotypic correlations between overall serum $\mathrm{Ca}, \mathrm{P}, \mathrm{Mg}$, and $\mathrm{K}$ concentrations and health disorders during the first $8 \mathrm{~d}$ after calving are shown in Table 5. Calcium, Mg, and $\mathrm{K}$ concentrations had high negative correlations with the related subclinical disorders; this was not the case with $\mathrm{P}$. Serum Ca concentrations had a low positive correlation with BCS and a low negative correlation with BHB; moreover, correlations with most health disorders were negative, either low (HypoP, HypoK, HyperP, LDA, RFM, MET, and DE) or moderate (MF, SCHMg). Correlations of $\mathrm{Mg}$ and $\mathrm{K}$ concentrations with health disorders were similar to those of Ca. Magnesium (but not $\mathrm{K}$ ) concentrations had a low positive correlation with BCS. For those health disorders that significant correlations were detected, all were negative albeit low. Regarding $\mathrm{P}$, only a high positive correlation with $\mathrm{Hy}$ perP and low correlations with MAST and UP were detected.

Statistically significant phenotypic correlations of serum macromineral concentrations on $\mathrm{d} 1$ and their changes from d 1 to 4 and d 1 to 8 after calving with health disorders during the first $8 \mathrm{~d}$ after calving are shown in Table 6. Calcium concentrations on $\mathrm{d} 1$ and their changes had similar correlations with the various health disorders as those presented in Table 5. Calcium concentration on d 1 was mostly correlated with low concentrations of the other macrominerals, with $\mathrm{Ca}-$ related disorders (SCHCa and MF) and MET, whereas Ca changes were correlated with RFM, MET, KET, DE, and INVCULL. Phosphorus concentration on d 1 had similar correlations with the same health disorders as those presented in Table 5, as well. Moreover, a negative correlation with BCS was detected. Phosphorus decrease over time was negatively correlated with HyperP and positively correlated with MF, RFM, and DE. High $\mathrm{Mg}$ concentration on d 1 was again positively correlated with BCS and negatively with SCHMg and MET. Magnesium changes were correlated with SCHCa, HypoP, BHB, LDA, MET, and DE. Potassium concentrations on $\mathrm{d} 1$ had also similar correlations with the same health disorders as those presented in Table 5. Potassium changes were significantly correlated with HyperP and SCHCa.

Statistically significant phenotypic correlations of MF, SCHCa, HypoP, HyperP, SCHMg, and HypoK with transition period health events are shown in Table 7. Correlations were low but follow the same pattern as those of the respective macromineral serum concentrations, definitely connecting these health conditions with each other.

\section{DISCUSSION}

This study aimed to estimate genetic parameters of subclinical and clinical diseases that occur during the first $8 \mathrm{~d}$ after calving. Detailed records were obtained including day-to-day clinical examination of cows by the same veterinarian. 


\section{$\mathrm{SCHCa}$}

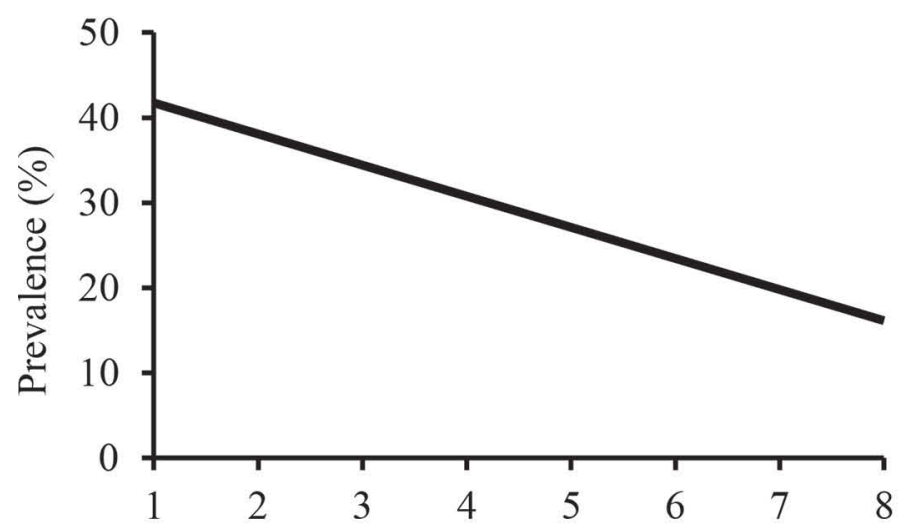

\section{SCHMg}

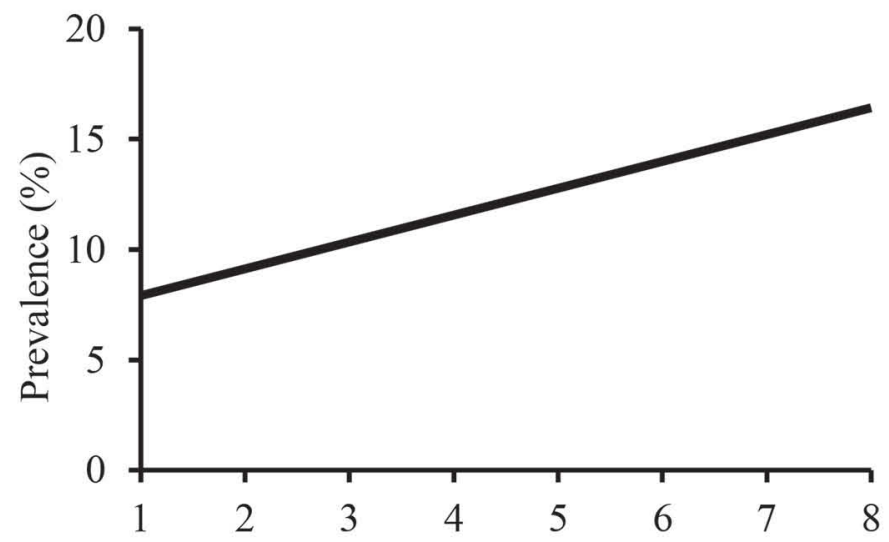

HyperP

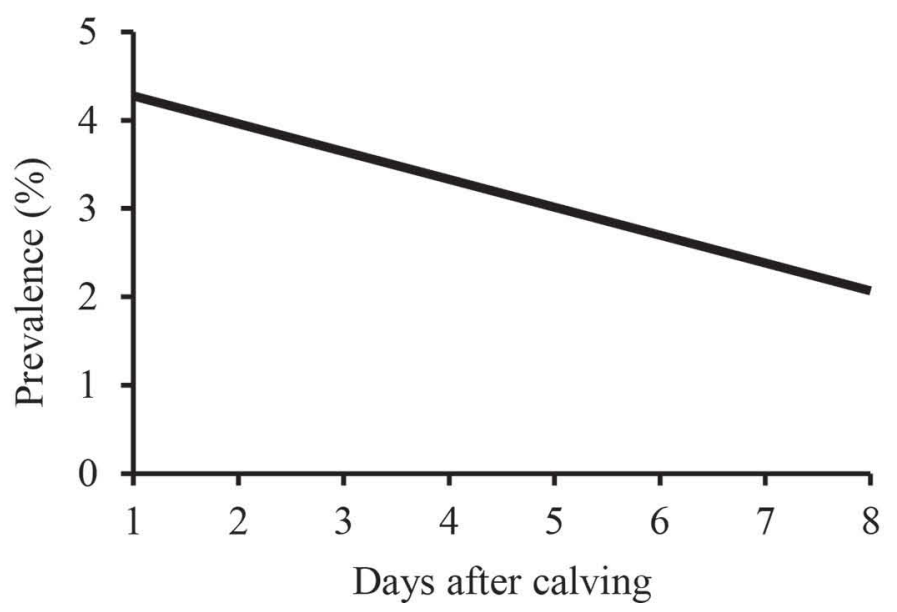

HypoP

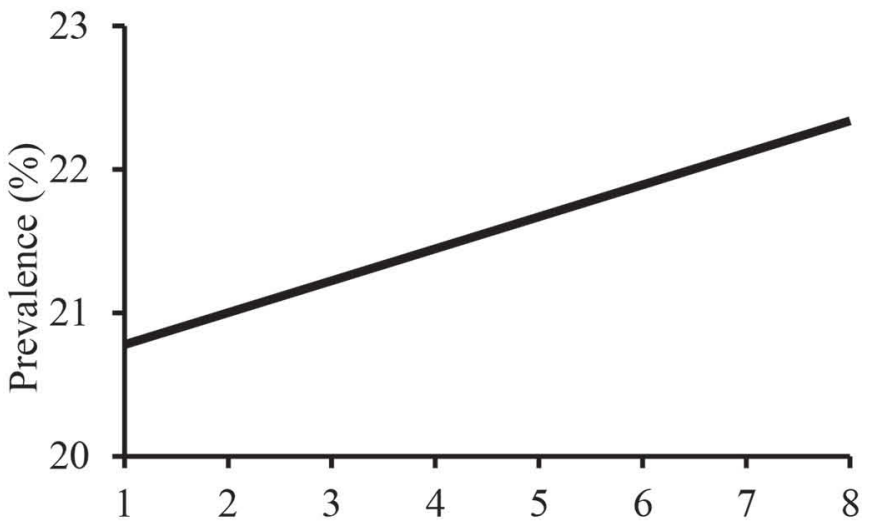

HypoK

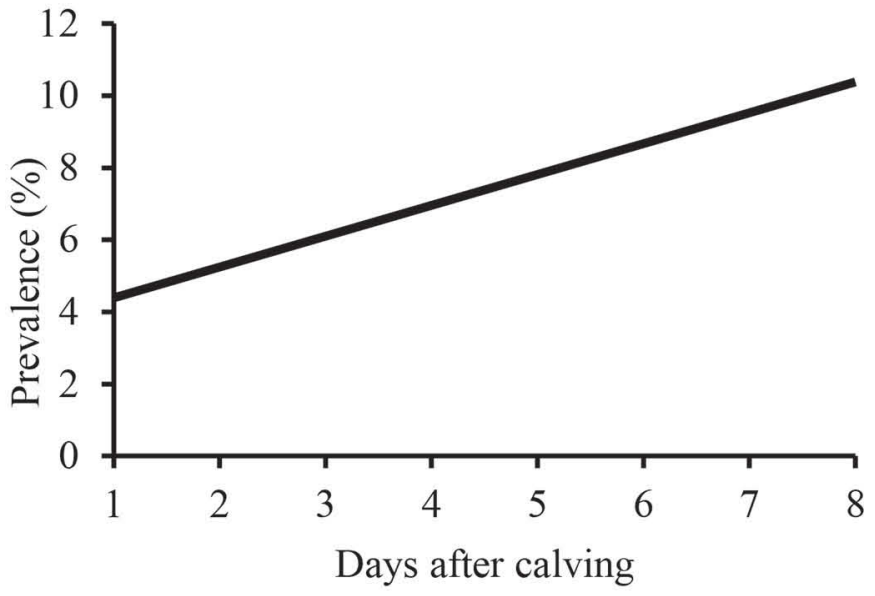

Figure 1. Prevalence of subclinical hypocalcemia (SCHCa), hypophosphatemia (HypoP), hypomagnesemia (SCHMg), hypokalemia (HypoK), and hyperphosphatemia (HyperP) across all lactations, during the first $8 \mathrm{~d}$ after calving based on third order fixed regression polynomials.

Incidence of health disorders was estimated during the first $8 \mathrm{~d}$ after calving, and a mixed model was used for the estimation of the day-to-day prevalence, which was modeled as a third polynomial fixed regression on days postpartum. The latter gave an accurate mapping of the health status of the population in study. 


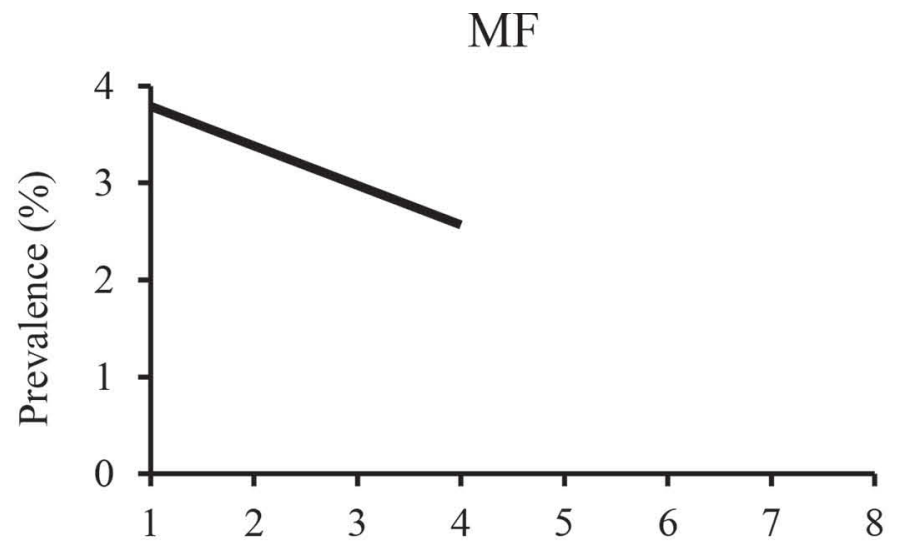

LDA

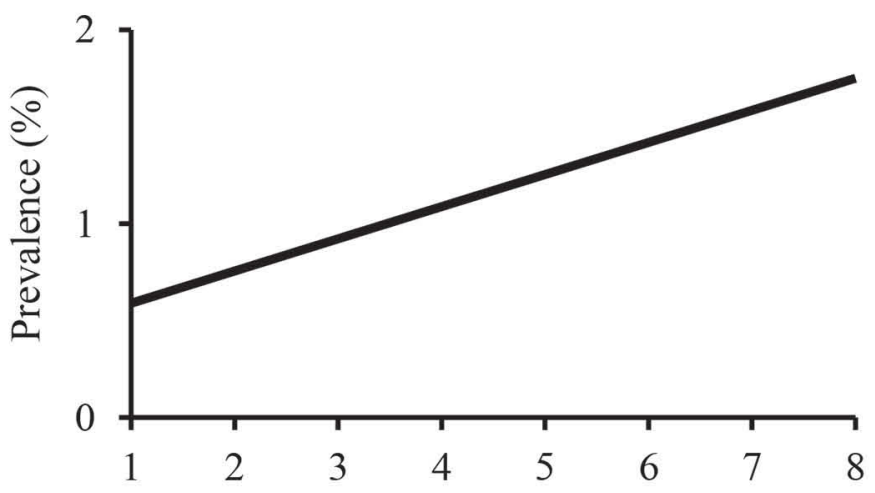

MAST

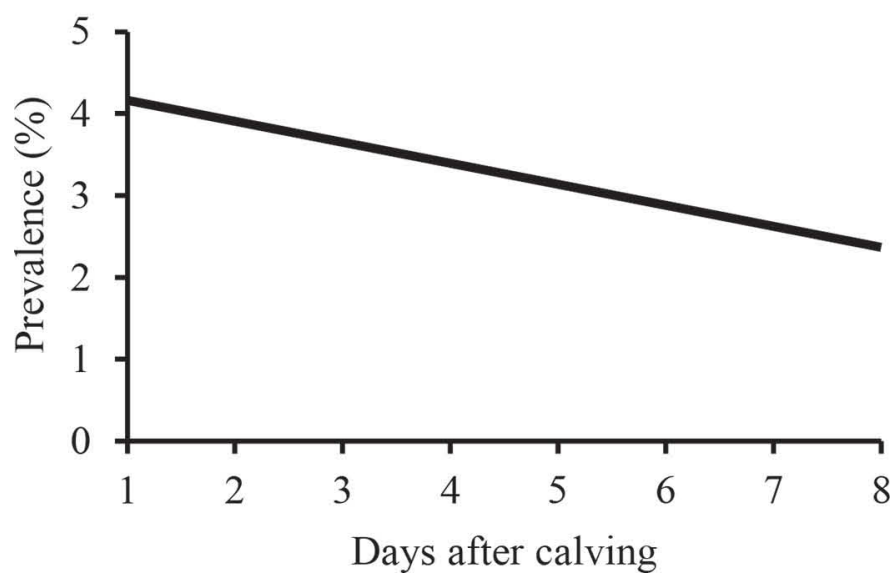

Figure 2. Prevalence of milk fever (MF), left displacement of abomasum (LDA), and mastitis (MAST) across all lactations, during the first $8 \mathrm{~d}$ after calving based on third order fixed regression polynomials.

Prevalence in this study is in agreement with those of Reinhardt et al. (2011) regarding SCHCa, of Staufenbiel (2002) and Macrae et al. (2006) regarding HypoP and HyperP, of Masoero et al. (2003) regarding SCHMg, and of Peek and Divers (2008) regarding HypoK. Moreover, incidence and prevalence of major clinical diseases recorded in this study were very similar to those reported in the literature (Kelton et al., 1998; Heringstad et al., 2005; Melendez and Risco, 2005; LeBlanc, 2008). Therefore, our estimations of various genetic parameters are concurrent with the global Holstein population kept under similar management practices.

Heritabilities of $\mathrm{Ca}, \mathrm{P}, \mathrm{Mg}$, and $\mathrm{K}$ serum concentrations have only recently been reported (Tsiamadis et al., 2016). Heritabilities of SCHCa, HypoP, HyperP, $\mathrm{SCHMg}$, and HypoK estimated in this study are reported for the first time in the literature. They were low to moderate but generally within the range reported for other traits such as milk yield $\left(\mathrm{h}^{2}=0.20-0.50\right.$; Castillo-Juarez et al., 2000; Windig et al., 2006; Bastin et al., 2011), SCC $\left(\mathrm{h}^{2}=0.03-0.11\right.$; Koeck et al., 2012; Heringstad et al., 2006), and longevity $\left(\mathrm{h}^{2}=0.01-0.36\right.$; Veerkamp and Brotherstone, 2001; Jamrozik et al., 2008), which are already used in breeding programs. Heringstad et al. (2007) reported potential for selection against metabolic disease resistance and several studies investigated the genetic basis of noninfectious disease resistance (Lin et al., 1989; Lyons et al., 1991; Abdel-Azim et al., 2005). Substantial and statistically significant genetic variance estimates derived in the present study corroborate these assertions.

At the same time, low heritability estimates suggest that environmental factors have a strong influence in the etiology of the studied traits. Nutrition, management, and housing of cows during the transition period emerge as critical factors for prevention of these health disorders in the short term. Nevertheless, genetic selection for resistance for these macromineral deficiency traits could be effective and add permanent benefits to successfully address the problem in the long term, thereby complementing management practices.

Heritability of BHB in the present study was not statistically significant $\left(\mathrm{h}^{2}=0.073 \pm 0.077\right)$. Oikonomou et al. (2008b) also reported heritability estimates in primiparous Holstein cows $\left(\mathrm{h}^{2}=0.25 \pm 0.18\right)$, which were not statistically significant. However, recently, van der Drift et al. (2012) in a study of 1,772 Holstein cows of various parities between 5 and $60 \mathrm{~d}$ after calving from 123 herds, using a similar animal model, reported a heritability estimate of $0.17 \pm 0.06(P<0.001)$. This higher heritability estimate can be attributed to the much wider sampling period (1 blood sample between 5 to $60 \mathrm{~d}$ after calving), which possibly resulted in a higher incidence of hyperketonemia. The heritability estimate of BCS was statistically significant in the present study $\left(\mathrm{h}^{2}=0.20 \pm 0.10\right)$. Koenen et al. (2001), Veerkamp and Brotherstone (2001), and Oikonomou et al. (2008b) reported higher estimates $(0.28-0.50)$ that 
Table 3. Variances and heritability estimates of subclinical hypocalcemia (SCHCa), hypophosphatemia (HypoP), hypomagnesemia (SCHMg), hypokalemia (HypoK), and hyperphosphatemia (HyperP) by days after calving from random regression model analyses ${ }^{1}$

\begin{tabular}{|c|c|c|c|c|c|}
\hline Trait & $\begin{array}{l}\text { Day after } \\
\text { calving }\end{array}$ & $\sigma_{p}^{2}$ & $\sigma_{\alpha}^{2}$ & $\sigma_{r}^{2}$ & $\mathrm{~h}^{2}$ \\
\hline \multirow[t]{2}{*}{$\mathrm{SCHCa}$} & 1 & $0.22(0.01)^{* *}$ & $0.06(0.01)^{* *}$ & $0.16(0.01)^{* *}$ & $0.25(0.03)^{* *}$ \\
\hline & 8 & $0.14(0.01)^{* *}$ & $0.02(0.01)^{*}$ & $0.12(0.01)^{* *}$ & $0.13(0.06)^{*}$ \\
\hline \multirow[t]{2}{*}{ HypoP } & 1 & $0.16(0.01)^{* *}$ & $0.03(0.01)^{* *}$ & $0.12(0.01)^{* *}$ & $0.21(0.03)^{* *}$ \\
\hline & 2 & $0.16(0.01)^{* *}$ & $0.03(0.004)^{* *}$ & $0.14(0.01)^{* *}$ & $0.18(0.02)^{* *}$ \\
\hline \multirow[t]{4}{*}{ SCHMg } & 1 & $0.07(0.003)^{* *}$ & $0.03(0.003)^{* *}$ & $0.04(0.003)^{* *}$ & $0.38(0.04)^{* *}$ \\
\hline & 2 & $0.09(0.004)^{* *}$ & $0.02(0.002)^{* *}$ & $0.06(0.003)^{* *}$ & $0.27(0.03)^{* *}$ \\
\hline & 4 & $0.14(0.006)^{* *}$ & $0.02(0.002)^{* *}$ & $0.13(0.006)^{* *}$ & $0.12(0.01)^{* *}$ \\
\hline & 8 & $0.13(0.006)^{* *}$ & $0.01(0.006)^{*}$ & $0.11(0.008)^{* *}$ & $0.11(0.05)^{*}$ \\
\hline \multirow[t]{3}{*}{ HypoK } & 1 & $0.05(0.002)^{* *}$ & $0.005(0.002)^{*}$ & $0.05(0.002)^{* *}$ & $0.10(0.03)^{*}$ \\
\hline & 2 & $0.06(0.003)^{* *}$ & $0.005(0.001)^{* *}$ & $0.05(0.003)^{* *}$ & $0.08(0.02)^{* *}$ \\
\hline & 4 & $0.06(0.003)^{* *}$ & $0.005(0.001)^{* *}$ & $0.06(0.003)^{* *}$ & $0.08(0.02)^{* *}$ \\
\hline
\end{tabular}

${ }^{1}$ Phenotypic $\left(\sigma_{p}^{2}\right)$, genetic $\left(\sigma_{\alpha}^{2}\right)$, and residual variances $\left(\sigma_{r}^{2}\right)$ and heritability $\left(\mathrm{h}^{2}\right)$ estimations (SE in parentheses).

${ }^{*} P<0.05,{ }^{* *} P<0.01,{ }^{* * *} P<0.001$.

were statistically significant. Others (Jones et al., 1999; Dechow et al., 2001; Bastin et al., 2010) have reported lower estimates (0.07-0.20), which are similar to our results. Heritability estimates of BCS tend to be larger in mid to late lactation (Dechow et al., 2001), and it is likely that the focus of this study on the first week after calving could have led to this moderate estimate.

The present study's estimates of MF heritability $\left(\mathrm{h}^{2}\right.$ $=0.07-0.11)$ are in agreement with those of Dyrendahl et al. (1972), Uribe et al. (1995), Pryce et al. (1997), Van Dorp et al. (1998), and Heringstad et al. (2005). These, however, are generally lower than estimates re- ported by Lin et al. (1989), Lyons et al. (1991), and Abdel-Azim et al. (2005; $\left.\mathrm{h}^{2}=0.30-0.40\right)$. Differences in estimates can be attributed to methodology of statistical analysis, data collection (farm records), and type and age of the population studied.

Our heritability estimates for LDA $\left(\mathrm{h}^{2}=0.18-0.31\right)$ are similar to those reported by Uribe et al. (1995) $\left(\mathrm{h}^{2}=0.304 \pm 0.005\right.$, across lactation with a threshold model). This is higher than other estimates from linear models reported by Lyons et al. (1991), Appuhamy et al. (2009), and Koeck et al. (2013). Moreover, Wolf et al. (2001) and Hamann et al. (2004) with the use of

Table 4. Variances and heritability estimates of milk fever (MF), left displacement of abomasum (LDA), and mastitis (MAST) by days after calving from random regression model analyses ${ }^{1}$

\begin{tabular}{|c|c|c|c|c|c|}
\hline Trait & $\begin{array}{l}\text { Day after } \\
\text { calving }\end{array}$ & $\sigma_{p}^{2}$ & $\sigma_{\alpha}^{2}$ & $\sigma_{r}^{2}$ & $\mathrm{~h}^{2}$ \\
\hline \multirow[t]{4}{*}{$\mathrm{MF}$} & 1 & $0.046(0.002)^{* * *}$ & $0.003(0.001)^{* * *}$ & $0.043(0.002)^{* * *}$ & $0.07(0.02)^{* * *}$ \\
\hline & 2 & $0.029(0.001)^{* * *}$ & $0.002(0.001)^{* * *}$ & $0.026(0.001)^{* * *}$ & $0.08(0.02)^{* * *}$ \\
\hline & 4 & $0.008(0.000)^{* * *}$ & $0.001(0.000)^{* *}$ & $0.007(0.000)^{* * *}$ & $0.11(0.03)^{* *}$ \\
\hline & 8 & - & - & - & - \\
\hline \multirow[t]{4}{*}{ LDA } & 1 & $0.01(0.000)^{* * *}$ & $0.002(0.000)^{* * *}$ & $0.01(0.000)^{* * *}$ & $0.24(0.03)^{* * *}$ \\
\hline & 2 & $0.01(0.000)^{* * *}$ & $0.002(0.000)^{* * *}$ & $0.01(0.000)^{* * *}$ & $0.19(0.02)^{* * *}$ \\
\hline & 4 & $0.01(0.000)^{* * *}$ & $0.003(0.000)^{* * *}$ & $0.01(0.000)^{* * *}$ & $0.26(0.02)^{* * *}$ \\
\hline & 8 & $0.02(0.001)^{* * *}$ & $0.006(0.001)^{* * *}$ & $0.01(0.001)^{* * *}$ & $0.31(0.05)^{* * *}$ \\
\hline \multirow[t]{4}{*}{ MAST } & 1 & $0.04(0.002)^{* * *}$ & $0.01(0.001)^{* * *}$ & $0.02(0.001)^{* * *}$ & $0.36(0.03)^{* * *}$ \\
\hline & 2 & $0.03(0.001)^{* * *}$ & $0.01(0.001)^{* * *}$ & $0.02(0.001)^{* * *}$ & $0.41(0.03)^{* * *}$ \\
\hline & 4 & $0.04(0.002)^{* * *}$ & $0.01(0.001)^{* * *}$ & $0.03(0.001)^{* * *}$ & $0.18(0.02)^{* * *}$ \\
\hline & 8 & $0.03(0.001)^{* * *}$ & $0.004(0.002)^{*}$ & $0.02(0.002)^{* * *}$ & $0.15(0.06)^{*}$ \\
\hline
\end{tabular}

${ }^{1}$ Phenotypic $\left(\sigma_{p}^{2}\right)$, genetic $\left(\sigma_{\alpha}^{2}\right)$, and residual variances $\left(\sigma_{r}^{2}\right)$ and heritability $\left(\mathrm{h}^{2}\right)$ estimations (SE in parentheses).

${ }^{*} P<0.05$; ** $P<0.01$; *** $P<0.001$. 
threshold models reported heritability estimates above 0.50 . The moderate to high heritability estimates of the present study can be attributed to a more accurate recording of the displacement made by the veterinarian and to the binary nature of the trait that posed no ambiguity of the severity of the disease and thus of the certainty of the diagnosis.

Heritability estimates for MAST vary across studies. Lin et al. (1989) reported heritabilities of $0.19 \pm$ $0.08,0.31 \pm 0.10$, and $0.18 \pm 0.09$ for the first, second, and third+ lactation, respectively. Uribe et al. (1995) reported similar estimates for first lactation cows $\left(\mathrm{h}^{2}\right.$ $=0.15 \pm 0.05)$ but for all lactations estimates were zero. Zwald et al. (2004) and Heringstad et al. (2005) reported much lower estimates $\left(\mathrm{h}^{2}=0.09 \pm 0.01\right)$; more recently, Pérez-Cabal et al. (2009) and Vazquez et al. (2009) also reported similar heritabilities $\left(\mathrm{h}^{2}=\right.$ 0.09 and $h^{2}=0.13$, respectively), whereas Koeck et al. (2013) estimated the heritability of clinical MAST at $0.02 \pm 0.004$. However, all these studies estimated MAST heritability across lactation. Our estimates $\left(h^{2}\right.$ $=0.15-0.41)$ cover a small portion of the entire lactation, only the first $8 \mathrm{~d}$. Considering that clinical MAST immediately after calving is influenced by factors such as dry period management and compromised immune status due to calving (Kimura et al., 2006; LeBlanc, 2010), this may well be a different trait, which, based on our results, could potentially respond to selection.
The present study did not detect any significant genetic correlation of $\mathrm{Ca}, \mathrm{P}, \mathrm{Mg}$, and $\mathrm{K}$ serum concentrations and BCS with any postpartum health disorders. The absence of genetic correlations could be attributed to the multifactorial etiology of most of these health events: infectious agents may co-exist with metabolic and managerial deficiencies. Moreover, this lack of genetic correlation may support the idea that these traits are controlled genetically by different genes and individual selection should be applied. Contrary to expectations, this study did not find a significant genetic correlation between SCHCa and MF. However, considering the disease definitions, MF cases were defined as standing (showing mild ataxia, excitability, muscle tremors, and reduced ruminal motility) or recumbent cows; therefore, MF definition was solely based on symptoms and not in any serum $\mathrm{Ca}$ measurement. Furthermore, this absence of genetic correlation could also be attributed to the low incidence of MF. In this study, recumbent cows were immediately treated with intravenous $\mathrm{Ca}$ solutions, rendering the measurement of serum Ca concentrations meaningless. Moreover, it is known that there is no specific threshold of Ca serum concentrations that always results in recumbent cows. Regarding the absence of any genetic correlation of the remaining macrominerals with other health disorders, this may also be attributed to the multifactorial etiology and to the low incidence of some of the health

Table 5. Statistically significant phenotypic correlations of serum $\mathrm{Ca}, \mathrm{P}, \mathrm{Mg}$, and $\mathrm{K}$ concentrations with BCS, $\mathrm{BHB}$, and health disorder traits during the first $8 \mathrm{~d}$ after calving (SE in parentheses) ${ }^{1}$

\begin{tabular}{lcccc}
\hline Trait $^{2}$ & $\mathrm{Ca}$ & $\mathrm{P}$ & $\mathrm{Mg}$ & $\mathrm{K}$ \\
\hline BCS & $0.11(0.03)^{* *}$ & $-0.06(0.03) \dagger$ & $0.14(0.03)^{* * *}$ & $-0.06(0.03) \dagger$ \\
BHB & $-0.13(0.03)^{* * *}$ & $\mathrm{NS}$ & $\mathrm{NS}$ & $-0.09(0.03)^{*}$ \\
SCHCa & $-0.60(0.02)^{* * *}$ & $\mathrm{NS}$ & $-0.09(0.03)^{*}$ & $-0.10(0.03)^{*}$ \\
HypoP & $-0.06(0.03)^{*}$ & $\mathrm{NS}$ & $\mathrm{NS}$ & $\mathrm{NS}$ \\
SCHMg & $-0.22(0.03)^{* * *}$ & $\mathrm{NS}$ & $-0.56(0.02)^{* * *}$ & $-0.10(0.03)^{*}$ \\
HypoK & $-0.17(0.03)^{* * *}$ & $\mathrm{NS}$ & $-0.05(0.03) \dagger$ & $-0.48(0.02)^{* * *}$ \\
HyperP & $-0.07(0.3)^{*}$ & $0.46(0.03)^{* * *}$ & $-0.08(0.03)^{* *}$ & $\mathrm{NS}$ \\
MF & $-0.32(0.03)^{* * *}$ & $\mathrm{NS}$ & $\mathrm{NS}$ & $-0.11(0.03)^{* *}$ \\
RFM & $-0.14(0.03)^{* * *}$ & $\mathrm{NS}$ & $-0.10(0.03)^{*}$ & $-0.14(0.03)^{* * *}$ \\
MET & $-0.18(0.03)^{* * *}$ & $\mathrm{NS}$ & $-0.15(0.03)^{* * *}$ & $-0.13(0.03)^{* * *}$ \\
MAST & $\mathrm{NS}$ & $0.12(0.03)^{* * *}$ & $-0.06(0.03) \dagger$ & $\mathrm{NS}$ \\
LDA & $-0.15(0.03)^{* * *}$ & $\mathrm{NS}$ & $-0.07(0.03)^{*}$ & $-0.06(0.03) \dagger$ \\
RDA & $\mathrm{NS}$ & $\mathrm{NS}$ & $\mathrm{NS}$ & $\mathrm{NS}$ \\
KET & $-0.05(0.03) \dagger$ & $\mathrm{NS}$ & $\mathrm{NS}$ & $\mathrm{NS}$ \\
UP & $\mathrm{NS}$ & $\mathrm{NS}$ & $\mathrm{NS}$ & $\mathrm{NS}$ \\
INVCULL & $-0.09(0.03)^{*}$ & $\mathrm{NS}$ & $\mathrm{NS}$ & $\mathrm{NS}$ \\
DE & & $\mathrm{NS}$ & $0.06(0.03) \dagger$ & $-0.12(0.03)^{* * *}$ \\
\hline
\end{tabular}

${ }^{1}$ Single record per animal, bivariate analysis.

${ }^{2} \mathrm{SCHCa}=$ subclinical hypocalcemia, HypoP $=$ hypophosphatemia, $\mathrm{SCHMg}=$ subclinical hypomagnesemia, HypoK = hypokalemia, HyperP $=$ hyperphosphatemia, MF = milk fever, RFM = retained fetal membranes, $\mathrm{MET}=$ metritis, MAST $=$ mastitis, $\mathrm{LDA}=$ left displacement of abomasum, $\mathrm{RDA}=$ right displacement of abomasum, KET $=$ clinical ketosis, UP $=$ uterine prolapse, INVCULL $=$ involuntary culling, DE $=$ death.

${ }^{*} P<0.05 ;{ }^{* *} P<0.01 ;{ }^{* * *} P<0.001 ; \dagger 0.05 \leq P \leq 0.10$. 
TSIAMADIS ET AL.

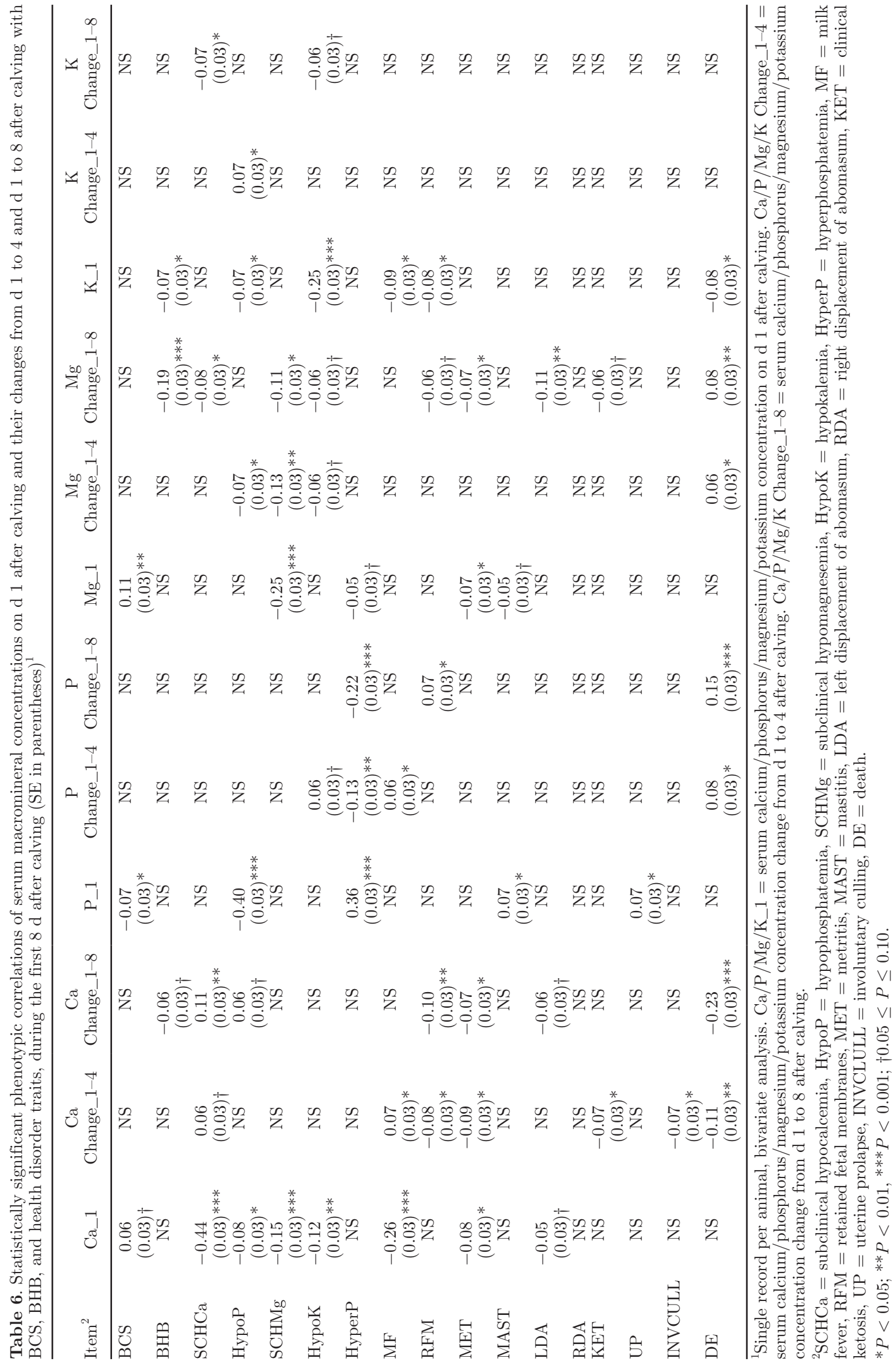


disorders (e.g., MET, MAST, and KET). On the other hand, the lack of any significant genetic correlation in this study may be incidental. Therefore, as this is the first study of its kind, the genetic analysis of other independent data sets may shed more light on this issue; more research is needed to clarify these issues.

The reported phenotypic association of clinical and subclinical hypocalcemia with various diseases after calving is based almost solely on pathophysiology; because of the central metabolic role of $\mathrm{Ca}$, it is generally assumed that $\mathrm{P}$ and $\mathrm{Mg}$ serum concentrations are associated with the same postpartum diseases through their relation with Ca metabolism (Rude, 1998; Goff, 2000; DeGaris and Lean, 2008). In a study of 2,190 cows from 33 herds, Curtis et al. (1983) showed that cows with clinical hypocalcemia (MF) were at greater risk of developing dystocia (6.5 times), RFM (3.2 times), KET (8.9 times), and MAST (8.1 times). Martinez et al. (2012) found that cows with low serum Ca have higher BHB concentrations. However, large-scale research-based evidence for any association of subclinical macromineral-related disorders with postpartum cow health is lacking. In the present study, statistically significant phenotypic correlations of serum concentrations of the 4 major macrominerals and the corresponding subclinical disorders with the early postpartum disease cascade in dairy cows are reported for the first time. A strong association with energy metabolism is evident both at the KET and BHB, as well as the BCS levels, with serious indirect and direct implications for future reproductive performance (RFM, MET, and UP), MAST, and replacement rates (LDA, INVCULL, and DE). The correlation of HyperP with MAST is a novel finding and the exact mechanism of this association has to be further investigated. These results highlight not only the need for genetic selection against these subclinical disorders, which is feasible based on our heritability estimates, but also for enhanced implementation of pertinent management practices.

Herd management during early postpartum is a challenge for modern dairy farms. The ability of an animal to maintain normal serum macromineral concentrations is consistent with the successful management of the numerous health events after calving. Rapid metabolic changes of animals combined with stressors such as nutritional and grouping changes further compromise immunity status, favor metabolic and infectious diseases, and downgrade productivity and welfare. Postpartum health monitoring programs are implemented in many dairy farms worldwide because they greatly contribute to the early recognition and proper treatment of sick animals (Risco, 2011). Obviously, genetic selection can provide a valuable tool, as well. Standardized health monitoring programs across regions and countries could 
provide accurate phenotype information for novel functional traits, the discovery of their genetic markers, and finally, the creation of a new index ("disease resistance early postpartum"). This is, indeed, a very exciting prospect.

\section{CONCLUSIONS}

More research is needed on this issue, but results of the present study clearly indicate that subclinical $\mathrm{Ca}, \mathrm{P}, \mathrm{Mg}$, and $\mathrm{K}$ disorders during the first week after calving are heritable traits. Moreover, significant heritability estimates of BCS and MF, MAST, and LDA during the same period were also derived. These genetic parameters can potentially be used to develop health indices for the selection of dairy cows that will effectively resist health challenges immediately after calving. Phenotypic correlations of high prevalence subclinical macromineral disorders with clinical diseases reveal a deeper interrelationship among these traits and stress the need for both innovative genetic selection and effective management practices.

\section{REFERENCES}

Abdel-Azim, G. A., A. E. Freeman, M. E. Kehrli, S. C. Kelm, J. L. Burton, A. L. Kuck, and S. Schnell. 2005. Genetic basis and risk factors for infectious and noninfectious diseases in US Holsteins. I. Estimation of genetic parameters for single diseases and general health. J. Dairy Sci. 88:1199-1207. http://dx.doi.org/10.3168/jds. S0022-0302(05)72786-7.

Appuhamy, J. A. D. R. N., B. G. Cassell, and J. B. Cole. 2009. Phenotypic and genetic relationships of common health disorders with milk and fat yield persistencies from producer-recorded health data and test-day yields. J. Dairy Sci. 92:1785-1795. http://dx.doi.org/ http://dx.doi.org/10.3168/jds.2008-1591.

Bastin, C., N. Gengler, and H. Soyeurt. 2011. Phenotypic and genetic variability of production traits and milk fatty acid contents across days in milk for Walloon Holstein first-parity cows. J. Dairy Sci. 94:4152-4163. http://dx.doi.org/10.3168/jds.2010-4108.

Bastin, C., S. Loker, N. Gengler, A. Sewalem, and F. Miglior. 2010 Genetic relationships between body condition score and reproduction traits in Canadian Holstein and Ayrshire first-parity cows. J. Dairy Sci. 93:2215-2228. http://dx.doi.org/10.3168/jds.2009-2720.

Bruss, M. L. 2008. Lipids and ketones. Pages 81-115 in Clinical Biochemistry of Domestic Animals. 6th ed. J. J. Kaneko, W. J. Harvey, and L. M. Bruss, ed. Academic Press, San Diego, CA.

Castillo-Juarez, H., P. A. Oltenacu, R. W. Blake, C. E. Mcculloch, and E. G. Cienfuegos-Rivas. 2000. Effect of herd environment on the genetic and phenotypic relationships among milk yield, conception rate, and somatic cell score in Holstein cattle. J. Dairy Sci. 83:807814. http://dx.doi.org/10.3168/jds.S0022-0302(00)74943-5.

Correa, M. T., C. R. Curtis, H. N. Erb, J. M. Scarlett, and R. D. Smith. 1990. An ecological analysis of risk factors for postpartum disorders of Holstein-Friesian cows from thirty-two New York farms. J. Dairy Sci. 73:1515-1524. http://dx.doi.org/10.3168/jds. S0022-0302(90)78819-4.

Curtis, C. R., H. N. Erb, C. J. Sniffen, R. D. Smith, P. A. Powers, M. C. Smith, M. E. White, R. B. Hillman, and E. J. Pearson. 1983. Association of parturient hypocalcemia with eight periparturient disorders in Holstein cows. J. Am. Vet. Med. Assoc. 183:559-561.
Daly, J. A., and G. Ertingshausen. 1972. Direct method for determining inorganic phosphate in serum with the "CentrifiChem". Clin. Chem. 18:263-265.

Dechow, C. D., G. W. Rogers, and J. S. Clay. 2001. Heritabilities and correlations among body condition scores, production traits, and reproductive performance. J. Dairy Sci. 84:266-275. http://dx.doi org/10.3168/jds.S0022-0302(01)74476-1.

DeGaris, P. J., and I. J. Lean. 2008. Milk fever in dairy cows: A review of pathophysiology and control principles. Vet. J. 176:58-69. http://dx.doi.org/10.1016/j.tvjl.2007.12.029.

Divers, T. J., and S. F. Peek. 2008. Chapter 1-The Clinical Examination. Pages 3-15 in Rebhun's Diseases of Dairy Cattle. 2nd ed. T. J. D. F. Peek, ed. W.B. Saunders, St. Louis, MO.

Duffield, T. F., K. D. Lissemore, B. W. McBride, and K. E. Leslie. 2009. Impact of hyperketonemia in early lactation dairy cows on health and production. J. Dairy Sci. 92:571-580. http://dx.doi. org $/ 10.3168 /$ jds.2008-1507.

Dyrendahl, I., B. Henricson, and G. Jönsson. 1972. Clinical puerperal paresis and hypocalcaemia in cattle. A statistical and genetic investigation. Zentralbl. Veterinarmed. A 19:621-638.

Eggen, A. 2012. The development and application of genomic selection as a new breeding paradigm. Anim. Front. 2:10-15. http://dx.doi. org/10.2527/af.2011-0027

Ferguson, J. D., D. T. Galligan, and N. Thomsen. 1994. Principal descriptors of body condition score in Holstein cows. J. Dairy Sci 77:2695-2703

Gilmour, A. R., B. J. Gogel, B. R. Cullis, and R. Thompson. 2006 ASReml User Guide Release 2.0. VSN International Ltd., Hemel Hempstead, UK. http://www.vsni.co.uk/.

Goff, J. P. 2000. Pathophysiology of calcium and phosphorus disorders. Vet. Clin. North Am. Food Anim. Pract. 16:319-337.

Goff, J. P. 2004. Macromineral disorders of the transition cow. Vet Clin. North Am. Food Anim. Pract. 20:471-494. http://dx.doi org/10.1016/j.cvfa.2004.06.003.

Goff, J. P. 2006a. Major advances in our understanding of nutritional influences on bovine health. J. Dairy Sci. 89:1292-1301. http:// dx.doi.org/10.3168/jds.S0022-0302(06)72197-X.

Goff, J. P. 2006b. Macromineral physiology and application to the feeding of the dairy cow for prevention of milk fever and other periparturient mineral disorders. Anim. Feed Sci. Technol. 126:237257. http://dx.doi.org/10.1016/j.anifeedsci.2005.08.005.

Goff, J. P. 2008. The monitoring, prevention, and treatment of milk fever and subclinical hypocalcemia in dairy cows. Vet. J. 176:50-57. http://dx.doi.org/10.1016/j.tvjl.2007.12.020.

Gröhn, Y. T., and M. L. Bruss. 1990. Effect of diseases, production, and season on traumatic reticuloperitonitis and ruminal acidosis in dairy cattle. J. Dairy Sci. 73:2355-2363. http://dx.doi. org/10.3168/jds.S0022-0302(90)78918-7.

Grünberg, W. 2014. Treatment of phosphorus balance disorders. Vet. Clin. North Am. Food Anim. Pract. 30:383-408. http://dx.doi org/10.1016/j.cvfa.2014.03.002.

Hamann, H., V. Wolf, H. Scholz, and O. Distl. 2004. Relationships between lactational incidence of displaced abomasum and milk production traits in German Holstein cows. J. Vet. Med. Ser. A Physiol. Pathol. Clin. Med. 51:203-208. http://dx.doi.org/10.1111/ j.1439-0442.2004.00626.x.

Heringstad, B., Y. M. Chang, D. Gianola, and G. Klemetsdal. 2005. Genetic analysis of clinical mastitis, milk fever, ketosis, and retained placenta in three lactations of Norwegian red cows. J. Dairy Sci. 88:3273-3281. http://dx.doi.org/10.3168/jds.S00220302(05)73010-1.

Heringstad, B., D. Gianola, Y. M. Chang, J. Odegård, and G. Klemetsdal. 2006. Genetic associations between clinical mastitis and somatic cell score in early first-lactation cows. J. Dairy Sci. 89:22362244. http://dx.doi.org/10.3168/jds.S0022-0302(06)72295-0.

Heringstad, B., G. Klemetsdal, and T. Steine. 2007. Selection responses for disease resistance in two selection experiments with Norwegian red cows. J. Dairy Sci. 90:2419-2426. http://dx.doi. org $/ 10.3168 /$ jds.2006- 805 
Horst, R., and J. Goff. 2003. Prevalence of subclinical hypocalcemia in US dairy operations. J. Dairy Sci. 86(Suppl. 1):247.

Ingvartsen, K. L., R. J. Dewhurst, and N. C. Friggens. 2003. On the relationship between lactational performance and health: Is it yield or metabolic imbalance that cause production diseases in dairy cattle? A position paper. Livest. Prod. Sci. 83:277-308. http:// dx.doi.org/10.1016/S0301-6226(03)00110-6.

Jamrozik, J., J. Fatehi, and L. R. Schaeffer. 2008. Comparison of models for genetic evaluation of survival traits in dairy cattle: A simulation study. J. Anim. Breed. Genet. 125:75-83. http://dx.doi. org/10.1111/j.1439-0388.2007.00712.x.

Jones, H., I. White, and S. Brotherstone. 1999. Genetic evaluation of Holstein Friesian sires for daughter condition-score changes using a random regression model. Anim. Sci. 68:467-475.

Kelton, D. F., K. D. Lissemore, and R. E. Martin. 1998. Recommendations for recording and calculating the incidence of selected clinical diseases of dairy cattle. J. Dairy Sci. 81:2502-2509. http://dx.doi. org/10.3168/jds.S0022-0302(98)70142-0.

Kimura, K., T. A. Reinhardt, and J. P. Goff. 2006. Parturition and hypocalcemia blunts calcium signals in immune cells of dairy cattle. J. Dairy Sci. 89:2588-2595. http://dx.doi.org/10.3168/jds.S00220302(06)72335-9.

Koeck, A., F. Miglior, J. Jamrozik, D. F. Kelton, and F. S. Schenkel. 2013. Genetic associations of ketosis and displaced abomasum with milk production traits in early first lactation of Canadian Holsteins. J. Dairy Sci. 96:4688-4696. http://dx.doi.org/10.3168/ jds.2012-6408.

Koeck, A., F. Miglior, D. F. Kelton, and F. S. Schenkel. 2012. Alternative somatic cell count traits to improve mastitis resistance in Canadian Holsteins. J. Dairy Sci. 95:432-439. http://dx.doi. org/10.3168/jds.2011-4731.

Koenen, E. P. C., R. F. Veerkamp, P. Dobbelaar, and G. De Jong. 2001. Genetic analysis of body condition score of lactating Dutch Holstein and Red-and-White heifers. J. Dairy Sci. 84:1265-1270. http://dx.doi.org/10.3168/jds.S0022-0302(01)74588-2.

Larsen, T., G. Møller, and R. Bellio. 2001. Evaluation of clinical and clinical chemical parameters in periparturient cows. J. Dairy Sci. 84:1749-1758. http://dx.doi.org/10.3168/jds.S00220302(01)74610-3.

Lean, I. J., R. Van Saun, and P. J. Degaris. 2013. Energy and protein nutrition management of transition dairy cows. Vet. Clin. North Am. Food Anim. Pract. 29:337-366. http://dx.doi.org/10.1016/j. cvfa.2013.03.005.

LeBlanc, S. 2010. Monitoring metabolic health of dairy cattle in the transition period. J. Reprod. Dev. 56(Suppl.):S29-S35. http:// dx.doi.org/10.1262/jrd.1056S29.

LeBlanc, S. J. 2008. Postpartum uterine disease and dairy herd reproductive performance: A review. Vet. J. 176:102-114. http://dx.doi. org/10.1016/j.tvjl.2007.12.019.

Lin, H. K., P. A. Oltenacu, L. D. Van Vleck, H. N. Erb, and R. D. Smith. 1989. Heritabilities of and genetic correlations among six health problems in Holstein cows. J. Dairy Sci. 72:180-186. http:// dx.doi.org/10.3168/jds.S0022-0302(89)79095-0.

Littledike, E. T., J. A. Stuedemann, S. R. Wilkinson, and R. L. Horst. 1983. Grass tetany syndrome. Page 173 in Proceedings of John Lee Pratt International Symposium on the Role of Magnesium in Animal Nutrition. Virginia Polytechnic Institute and State University, Blacksburg.

Lyons, D. T., A. E. Freeman, and A. L. Kuck. 1991. Genetics of health traits in Holstein cattle. J. Dairy Sci. 74:1092-1100. http://dx.doi. org/10.3168/jds.S0022-0302(91)78260-X.

Macrae, A. I., D. A. Whitaker, E. Burrough, A. Dowell, and J. M. Kelly. 2006. Use of metabolic profiles for the assessment of dietary adequacy in UK dairy herds. Vet. Rec. 159:655-661. http://dx.doi. org/10.1136/vr.159.20.655.

Martinez, N., C. A. Risco, F. S. Lima, R. S. Bisinotto, L. F. Greco, E. S. Ribeiro, F. Maunsell, K. Galvão, and J. E. P. Santos. 2012 Evaluation of peripartal calcium status, energetic profile, and neutrophil function in dairy cows at low or high risk of developing uterine disease. J. Dairy Sci. 95:7158-7172. http://dx.doi. org/10.3168/jds.2012-5812.
Masoero, F., M. Moschini, and A. M. Pulimeno. 2003. Serum calcium and magnesium level in dairy cows at calving. Ital. J. Anim. Sci. 2 (Suppl.): $172-174$

Melendez, P., G. A. Donovan, C. A. Risco, R. Littell, and J. P. Goff, 2003. Effect of calcium-energy supplements on calving-related disorders, fertility and milk yield during the transition period in cows fed anionic diets. Theriogenology 60:843-854. http://dx.doi. org/10.1016/S0093-691X(03)00103-1.

Melendez, P., and C. A. Risco. 2005. Management of transition cows to optimize reproductive efficiency in dairy herds. Vet. Clin. North Am. Food Anim. Pract. 21:485-501. http://dx.doi.org/10.1016/j. cvfa.2005.02.008

Mulligan, F. J., and M. L. Doherty. 2008. Production diseases of the transition cow. Vet. J. 176:3-9. http://dx.doi.org/10.1016/j. tvj1.2007.12.018.

Mulligan, F. J., L. O'Grady, D. A. Rice, and M. L. Doherty. 2006. A herd health approach to dairy cow nutrition and production diseases of the transition cow. Anim. Reprod. Sci. 96:331-353. http:// dx.doi.org/10.1016/j.anireprosci.2006.08.011.

NRC. 2001. Nutrient Requirements of Dairy Cattle. 7th rev. ed. Natl. Acad. Sci., Washington, DC.

Oetzel, G. R. 2011. Diseases of Dairy Animals | Non-Infectious Diseases: Milk Fever. Pages 239-245 in Encyclopedia of Dairy Sciences (2nd ed.). J. W. Fuquay, ed. Academic Press, San Diego, CA.

Oikonomou, G., G. Arsenos, G. E. Valergakis, A. Tsiaras, D. Zygoyiannis, and G. Banos. 2008a. Genetic relationship of body energy and blood metabolites with reproduction in Holstein cows. J. Dairy Sci. 91:4323-4332. http://dx.doi.org/10.3168/jds.2008-1018.

Oikonomou, G., G. E. Valergakis, G. Arsenos, N. Roubies, and G. Banos. 2008b. Genetic profile of body energy and blood metabolic traits across lactation in primiparous Holstein cows. J. Dairy Sci. 91:2814-2822. http://dx.doi.org/10.3168/jds.2007-0965.

Peek, S. F., and T. J. Divers. 2008. Chapter 14-Metabolic diseases. Pages 590-605 in Rebhun's Diseases of Dairy Cattle. 2nd ed. T. J. D. F. Peek, ed. W.B. Saunders, St. Louis, MO.

Pérez-Cabal, M. A., G. de los Campos, A. I. Vazquez, D. Gianola, G. J. M. Rosa, K. A. Weigel, and R. Alenda. 2009. Genetic evaluation of susceptibility to clinical mastitis in Spanish Holstein cows. J. Dairy Sci. 92:3472-3480. http://dx.doi.org/10.3168/jds.2008-1978.

Pryce, J. E., R. F. Veerkamp, R. Thompson, W. G. Hill, and G. Simm. 1997. Genetic aspects of common health disorders and measures of fertility in Holstein Friesian dairy cattle. Anim. Sci. 65:353-360. http://dx.doi.org/10.1017/S1357729800008559.

Reinhardt, T. A., J. D. Lippolis, B. J. McCluskey, J. P. Goff, and R. L. Horst. 2011. Prevalence of subclinical hypocalcemia in dairy herds. Vet. J. 188:122-124. http://dx.doi.org/10.1016/j.tvjl.2010.03.025.

Risco, C. A. 2011. Management Considerations from Parturition to the End of the Voluntary Waiting Period to Optimize Health and Reproductive Performance. Pages 1-6 in Dairy Production Medicine. Blackwell Publishing Ltd, Hoboken, NJ.

Rude, R. K. 1998. Magnesium deficiency: A cause of heterogeneous disease in humans. J. Bone Miner. Res. 13:749-758. http://dx.doi. org/10.1359/jbmr.1998.13.4.749.

Sattler, N., and G. Fecteau. 2014. Hypokalemia syndrome in cattle. Vet. Clin. North Am. Food Anim. Pract. 30:351-357. http:// dx.doi.org/10.1016/j.cvfa.2014.04.004.

Sattler, N., G. Fecteau, C. Girard, and Y. Couture. 1998. Description of 14 cases of bovine hypokalaemia syndrome. Vet. Rec. 143:503507. http://dx.doi.org/10.1136/vr.143.18.503.

Schonewille, J. T., H. Everts, S. Jittakhot, and A. C. Beynen. 2008 Quantitative prediction of magnesium absorption in dairy cows. J. Dairy Sci. 91:271-278. http://dx.doi.org/10.3168/jds.2007-0304.

Sheldon, I. M., G. S. Lewis, S. LeBlanc, and R. O. Gilbert. 2006. Defining postpartum uterine disease in cattle. Theriogenology 65:15161530. http://dx.doi.org/10.1016/j.theriogenology.2005.08.021.

Staufenbiel, R. 2002. Neue Aspekte zum klinischen Bild und zur Therapie der Gebärparese des Rindes. Vet. Med. Rev. 26:12 V6.

Thilsing-Hansen, T., R. J. Jørgensen, and S. Østergaard. 2002. Milk fever control principles: A review. Acta Vet. Scand. 43:1-19. http://dx.doi.org/10.1186/1751-0147-43-1. 
Tsiamadis, V., G. Banos, N. Panousis, M. Kritsepi-Konstantinou, G. Arsenos, and G. E. Valergakis. 2016. Genetic parameters of calcium, phosphorus, magnesium, and potassium serum concentrations during the first 8 days after calving in Holstein cows. J. Dairy Sci. 99:5535-5544. http://dx.doi.org/10.3168/jds.2015-10787.

Uribe, H. A., B. W. Kennedy, S. W. Martin, and D. F. Kelton. 1995. Genetic parameters for common health disorders of Holstein cows. J. Dairy Sci. 78:421-430. http://dx.doi.org/10.3168/jds.S00220302(95)76651-6.

van der Drift, S. G. A., K. J. E. van Hulzen, T. G. Teweldemedhn, R. Jorritsma, M. Nielen, and H. C. M. Heuven. 2012. Genetic and nongenetic variation in plasma and milk $\beta$-hydroxybutyrate and milk acetone concentrations of early-lactation dairy cows. J. Dairy Sci. 95:6781-6787. http://dx.doi.org/10.3168/jds.2012-5640.

Van Dorp, T. E., J. C. Dekkers, S. W. Martin, and J. P. Noordhuizen. 1998. Genetic parameters of health disorders, and relationships with 305-day milk yield and conformation traits of registered Holstein cows. J. Dairy Sci. 81:2264-2270. http://dx.doi.org/10.3168/ jds.S0022-0302(98)75806-0.
Vazquez, A. I., K. A. Weigel, D. Gianola, D. M. Bates, M. A. PerezCabal, G. J. M. Rosa, and Y. M. Chang. 2009. Poisson versus threshold models for genetic analysis of clinical mastitis in US Holsteins. J. Dairy Sci. 92:5239-5247. http://dx.doi.org/10.3168/ jds.2009-2085

Veerkamp, R., and S. Brotherstone. 2001. Analysis of censored survival data using random regression models. Anim. Sci. 1994:1-10.

Windig, J. J., M. P. L. Calus, B. Beerda, and R. F. Veerkamp. 2006 Genetic correlations between milk production and health and fertility depending on herd environment. J. Dairy Sci. 89:1765-1775. http://dx.doi.org/10.3168/jds.S0022-0302(06)72245-7.

Wolf, V., H. Hamann, H. Scholz, and O. Distl. 2001. Influences on the occurrence of abomasal displacements in German Holstein cows. Dtsch. Tierarztl. Wochenschr. 108:403-408.

Zwald, N. R., K. A. Weigel, Y. M. Chang, R. D. Welper, and J. S. Clay. 2004. Genetic selection for health traits using producer-recorded data. II. Genetic correlations, disease probabilities, and relationships with existing traits. J. Dairy Sci. 87:4295-4302. http:/ dx.doi.org/10.3168/jds.S0022-0302(04)73574-2. 